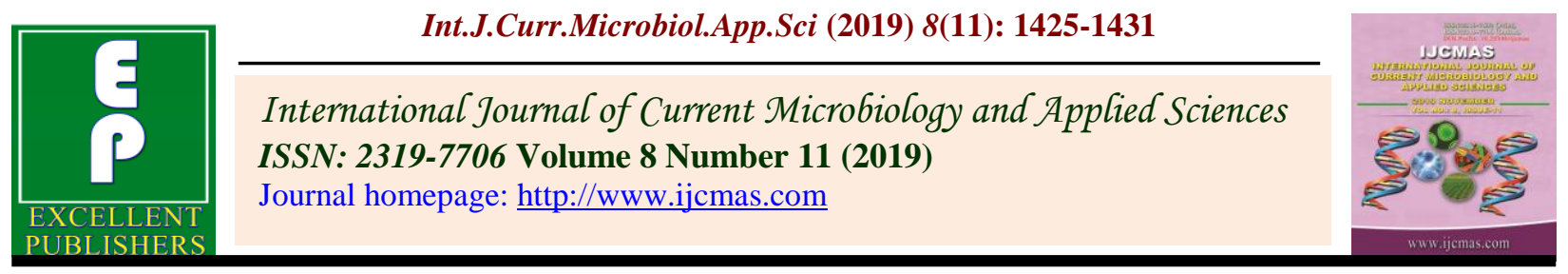

Original Research Article

https://doi.org/10.20546/ijcmas.2019.811.167

\title{
Therapeutic Alternations of Sero-biochemical Parameters and Electrolyte Concentration in Canine Parvo Virus Infection
}

\author{
S. Dash ${ }^{1 *}$, M.R. Das ${ }^{1}$, S.K. Senapati ${ }^{1}$, G.R. Jena ${ }^{1}$, S.K. Panda ${ }^{2}$, \\ S. Sathapathy ${ }^{3}$ and S.M. Nanda ${ }^{4}$ \\ ${ }^{1}$ Department of Veterinary Clinical Medicine, ${ }^{2}$ Department of Veterinary Pathology, \\ ${ }^{3}$ Department of Anatomy and Histology, ${ }^{4}$ Department of Veterinary and Animal Husbandry \\ Extension, CVSc. \& A.H., OUAT, Bhubaneswar-751003, India \\ *Corresponding author
}

Keywords

Alteration, Canine

Parvo virus,

Electrolyte

concentration, Sero-

biochemical,

Therapeutic

Article Info

Accepted:

12 October 2019

Available Online:

10 November 2019

\section{A B S T R A C T}

A total 64 numbers of dogs (36 male and 28 female) were divided age wise into three age groups viz. group A (1-3 months), group B (4-12 months) and group C (more than 12 months) with 24,26 and 14 animals in the said age groups respectively and sex wise into exotic (52 animals) and indigenous breeds (12 animals) to study the therapeutic alternations of sero-biochemical parameters and electrolyte concentration in Canine Parvo Virus infection after treatment with conventional method and conventional with administration of hyperimmune sera. Further, the exotic group included small (10 animals), medium (6 animals) and large (36 animals) sized dogs. It was found that the blood glucose level increased in all age groups of dogs in both the methods. The BUN level decreased in both the exotic and indigenous breeds of dogs after treatment with both the methods. The ALT and AST levels increased in exotic and indigenous breeds of dogs after the conventional treatment method. Further, the concentration of $\mathrm{Na}, \mathrm{P}$ and $\mathrm{Cl}$ increased in serum in indigenous and exotic breeds of dogs after treatment with both the methods. Further, the serum creatinine level decreased only in indigenous breed of dogs after treatment with conventional method.

\section{Introduction}

The Canine parvovirus infection (CPV) has become an important problem in dog population worldwide as it causes severe haemorrhagic gastroenteritis which may rapidly spreads in domestic dog populations as well as wild dogs with high morbidity (100\%) and frequent mortality up to $10 \%$ (Appel et $a l ., 1978)$ in treated dogs. Canine parvovirus enteritis is an acute, fatal and contagious gastrointestinal infection mostly seen in unvaccinated puppies from 6 to 20 weeks old are at greater risk and the disease is more 
severe in young dogs less than six months of age. Symptoms in puppies over two months include vomition, anorexia, nausea, haemorrhagic gastro enteritis, bloody diarrhoea with foul smell, leukopaenia and myocarditis and also result in the disease exhibiting high morbidity (100\%) and low mortality (Yilmaz et al., 2005; Yang et al.,2009) in treated puppies. The highest occurrence of CPV was during in summer followed by rainy season and winter also observed that the sexually intact dogs were at four times greater risk than spayed or neutered dogs and intact males were twice as likely as intact females in CPV enteritis (Biswas et al., 2006; Houston et al., 1996).

Factors that predispose parvovirus infection in puppies are lack of protective immunity, overcrowding of animals in a small space, unhygienic, stressful environmental conditions (Reddy et al., 2015; Ettinger et al., 1995). In neonatal animals, the virus replicates mitotically and FPV often causes cerebellar hypoplasia, whereas CPV causes myocarditis. In older animals' viral replication is limited to lymphoid and small intestinal cells causing temporary panleukopenia or lymphopenia. Virus has affinity towards intestine, bone marrow and lymph nodes and invades rapidly to mitotic cells, after an incubation period of 7-14 days causing intestinal impairment (Foster and Smith, 2011).

Invasion of the bone marrow causes a decrease in the white blood cell count leading to increased susceptibility to bacterial infections and sometimes showing shock due to endotoxemia (Debram, 2011). During the CPV infection, the Packed Cell Volume (PCV) and Total Erythrocyte Count (TEC) remained almost similar between healthy dogs and dogs affected with enteritis. The present study revealed the therapeutic alterations of sero-biochemical parameters and electrolyte concentration in Canine Parvo Virus infection.

\section{Materials and Methods}

A total 64 numbers of dogs (36 male and 28 female) were divided into three age groups viz. group A (1-3 months), group B (4-12 months) and group $\mathrm{C}$ (more than 12 months) with 24, 26 and 14 animals in the said age groups respectively.

Further, the above animals were divided into exotic (52 animals) and indigenous breeds (12 animals). The exotic group included small (10 animals), medium (6 animals) and large (36 animals) sized dogs. The blood samples were collected from the dogs treated both by conventional method and hyper immune sera before and after the treatment schedule and analysed for serum-biochemical parameters such as blood Glucose, Total Serum Protein (TP), Albumin, Globulin, A/G, BUN, Creatinine, ALT, AST and ALP by Semi automated blood analyzer using commercial reagent kits (CORAL PVT LTD). Further, the estimation of electrolyte salts like Serum Sodium, Potassium, Chloride and Bicarbonate was done by Inductively Compound Plasma Optical Emission Spectrometer (ICPOES) (PARKENMER AVIO-200). The data were analyzed using standard method of test significance (Snedecor and Cochran, 2004).

\section{Results and Discussion}

\section{Biochemical study in conventional method of treatment}

The exotic breeds were categorised depending of the size small, medium and large varieties whereas indigenous was taken without any subgroup.32 numbers of dogs were taken from the study and after the traditional treatment 21 number of dogs were survived and the data were collected and presented.

The blood glucose of the small, medium and large categories if exotic dog are $65.80 \mathrm{mg} / \mathrm{dl}$, 
$72.33 \mathrm{mg} / \mathrm{dl}$ and $68.89 \mathrm{mg} / \mathrm{dl}$ with an average of $68.69 \mathrm{mg} / \mathrm{dl}$ at the start of the treatment which were significantly increased $(\mathrm{P}<0.05)$ to $89.40 \mathrm{mg} / \mathrm{dl}, \quad 100.67 \mathrm{mg} / \mathrm{dl}$ and $86.91 \mathrm{mg} / \mathrm{dl}$ respectively, with an average of $89.74 \mathrm{mg} / \mathrm{dl}$. It was found that there was significantly increase $(\mathrm{P}<0.05)$ of blood glucose level in the dog after treatment, in the dog the values were $59.17 \mathrm{mg} / \mathrm{dl}$ and $110.00 \mathrm{mg} / \mathrm{dl}$ before and after treatment respectively. There was also significant rise $(\mathrm{P}<0.05)$ of glucose level in indigenous dog in post treatment. No change in serum total protein, albumin and globulin level of dogs observed in post treatment in both indigenous and exotic dogs. The serum creatinine levels of the exotic post treated dogs showed marginally lower values than pre-treated dogs without any significant $(\mathrm{P}>0.05)$ differ in exotic breed. Where as in indigenous the reduction of creatinine value was significant $(\mathrm{P}<0.05)$.

The overall BUN of exotic dog was 32.00 $\mathrm{mg} / \mathrm{dl}$ at the pre-treated dog which was significantly $(\mathrm{P}<0.05) \quad$ decreased to 25.21 $\mathrm{mg} / \mathrm{dl}$. Similarly, in case of indigenous also, the BUN values were significantly $(\mathrm{P}<0.05)$ decreased from $36.67 \mathrm{mg} / \mathrm{dl}$ to $26.00 \mathrm{mg} / \mathrm{dl}$. The AST values of the exotic and indigenous did not vary at the beginning of the treatment, but after the intervention, the AST values were significantly $(\mathrm{P}<0.05)$ reduced in indigenous breed but not in exotic one. There is significant higher $(\mathrm{P}<0.05)$ value of AST in exotic $(61.05 \mathrm{IU} / \mathrm{L})$ than indigenous breed (52.00IU/L). Irrespective of the size in exotic breed and indigenous breed, all the values of ALT and ALP were significantly higher in post-treatment than pre-treatment. Also, there is statistically difference of ALT and ALP in exotic dogs than indigenous dogs.

The serum electrolyte like sodium, potassium and chloride values of all the categories of exotic and indigenous breeds significantly increased in post therapeutic period without any significant difference among the breed. But serum bicarbonate level was neither affected with the therapy nor with the breed. The data collected from the 32 number of dogs before treatment and 21 dogs of both the breeds after treatment were categorised 3 age groups i.e. 1-3 months, 4-12 months and more than 12 months. The blood glucose levels in the most of the subgroups have significant increase $(\mathrm{P}<0.05)$ post treatment. There is no variation in the blood glucose level in different age groups of the particular group. There was significant lower $(\mathrm{P}<0.05)$ $(49.00 \mathrm{mg} / \mathrm{dl})$ glucose level in indigenous dog in more than 12 months of age than the exotic one $(65.20 \mathrm{mg} / \mathrm{dl})$. In $4-12$ months of age, indigenous dog has higher glucose level than the exotic dog.

The serum total protein level of indigenous dog was $3 \mathrm{gm} / \mathrm{dl}$ and 4-12 months of age whereas in exotic dog of same age group was found to be significantly $(\mathrm{P}<0.05)$ higher with value of $5.42 \mathrm{gm} / \mathrm{dl}$, whereas the dogs with more than 12 months of age the total protein of indigenous $(5.20 \mathrm{gm} / \mathrm{dl})$ dog was significantly higher $(\mathrm{P}<0.05)$ than the exotic $(4.60 \mathrm{gm} / \mathrm{dl}) \mathrm{dogs}$. The serum albumin did not vary significantly $(\mathrm{P}>0.05)$ between the breed irrespective of the age groups, whereas the albumin level of 4-12 months of age in exotic breed was significantly higher $(\mathrm{P}<0.05)(2.55$ $\mathrm{gm} / \mathrm{dl})$ than the indigenous breed $(1.30 \mathrm{gm} / \mathrm{dl})$. In all other age groups, no variation of globulin level was observed.

The serum creatinine level of the dogs of all the groups did not vary among the breeds before treatment but after the traditional therapy, exotic breeds are higher $(\mathrm{P}<0.05)$ creatinine level than the indigenous breeds at 4-12 months of age. The serum BUN level decreased with post treatment in all age groups both in exotic and indigenous but no significant variation was observed among the 3 age groups. The serum AST, ALT level of 
the dogs of different age groups did not vary before the therapy whereas, after therapy there was higher AST level (64.00 IU/L) in exotic breeds than indigenous breeds $(50.00$ IU/L).But in case of ALT, both in 1-3 months and 4-12 months of age indigenous breeds have significantly $(\mathrm{P}<0.05)$ lower ALT value than the exotic breeds. The serum ALP level of 1-3 months of age and more than 12 months of age in exotic breeds have a significant $(\mathrm{P}<0.05)$ lower value than their indigenous breed of corresponding age group at the beginning of the experiment. After the post therapy, in case of the 4-12 months of age, the level of serum ALP in exotic dogs showed higher ALP value than the indigenous one.

The serum $\mathrm{Na}$ level of the dogs were significantly $(\mathrm{P}<0.05)$ increased all age groups post therapeutic period, but no variation was observed or seen among the different age groups at the beginning and post therapeutic period except 4-12 months of age exotic breeds showed higher value than the indigenous ones. The serum potassium level also follows the same trend with the sodium level as electrolyte was supplemented during the therapeutic period. However, at pre and post therapeutic period at the age of 4-12 months, indigenous dog showed lower serum potassium level then the exotic ones. The serum Chloride and bicarbonate level of the dogs did not vary among the 3 age groups or both the breeds. However, post therapeutically there was improvement of Chloride status of all the age groups of both the breeds.

The blood glucose level of the male female dogs of exotic breed did not differ at pre and post therapeutic period but in case of indigenous breed males have significantly higher value than the female at both pre post therapeutic period. Total protein level of both indigenous and exotic breeds significantly $(\mathrm{P}<0.05)$ improved after post therapeutic period with ranged from $4.8 \mathrm{gm} / \mathrm{dl}$ to 5.77 $\mathrm{gm} / \mathrm{dl}$ in exotic breed and $3.02 \mathrm{gm} / \mathrm{dl}$ to 4.50 $\mathrm{gm} / \mathrm{dl}$ in indigenous breed. No variation was observed in male and female dogs in both the breeds. Serum albumin, globulin and $\mathrm{A} / \mathrm{G}$ ratio showed no significant changes with respect to therapeutic interventions and sex wise variations.

The creatinine levels of the dog before treatment ranged from $1.33 \mathrm{mg} / \mathrm{dl}$ to 1.95 $\mathrm{mg} / \mathrm{dl}$ in post therapeutic period and 0.70 $\mathrm{mg} / \mathrm{dl}$ to $1.35 \mathrm{mg} / \mathrm{dl}$ in post therapeutic period. No variations were also observed between the sexes of both the breed. Whereas the BUN of indigenous female was $47.00 \mathrm{mg} / \mathrm{dl}$ which was significantly higher $(\mathrm{P}<0.05)$ than its male counterpart $31.50 \mathrm{mg} / \mathrm{dl}$ in before treatment. After conventional treatment regimens the BUN level of the female of exotic dog was significantly higher $(\mathrm{P}<0.05)$ than the male dogs $(27.80 \mathrm{mg} / \mathrm{dl}$ vs $22.33 \mathrm{mg} / \mathrm{dl})$. Where as in case of indigenous dogs the reverse trend was seen i.e. the male dogs have significantly higher BUN than female counterpart (28.00 $\mathrm{mg} / \mathrm{dl}$ vs $24.00 \mathrm{mg} / \mathrm{dl}$ ).

From the enzymatic studies it was revealed that the indigenous male has significantly higher $(\mathrm{P}<0.05)$ AST $(54.00 \quad$ IU/L $)$ in comparison to female (50.00 IU/L) during post therapeutic period. But in exotic dogs no variation of AST was observed due to therapeutic interventions and sex variations. The serum ALT level of the male of indigenous dog has a lower value than the female dogs at both pre and post treatment. Similarly, the serum ALP level of the dogs before treatment in female of both the breed dog was found to be significantly higher than their male counterpart and which ranged from 141.36IU/L to190.50IU/L in female, where as in male it ranged from $103.93 \mathrm{IU} / \mathrm{L}$ to 149.00IU/L. After the therapy no sex affect was observed in exotic one. Where as in indigenous males have higher value than the female. 
The serum electrolyte level of sodium, potassium and chloride increased significantly in post treatment period irrespective of sex and breed in comparison to pre-treatment period. No variations of the electrolytes were observed at the beginning of the experiment between the sex in both the breeds but in post therapeutic period there was significantly higher $(\mathrm{P}<0.05)$ sodium, potassium and chloride level in the male of indigenous breed than the female one. Whereas no variation of all the electrolytes were seen among the sex in exotic breed.

The bicarbonate level of the serum did not vary between the sex of both the breed at pretreatment period but post treatment indigenous male has a higher bicarbonate value then its female counter parts $(20.00 \mathrm{~m}$ mole/litter vs $9.00 \mathrm{mmole} / \mathrm{litter}$ ). Whereas sex wise no variation was observed.

\section{Biochemical study in conventional method of treatment with administration of hyperimmune sera}

The blood glucose of the 3 categories of exotic breed (small, medium and large) after the administration of hyper immune serum was significantly higher then what was presented at the beginning.

The glucose level at the beginning of the treatment were $71.80 \mathrm{mg} / \mathrm{dl}, 66.00 \mathrm{mg} / \mathrm{dl}$ and71.39 $\mathrm{mg} / \mathrm{dl}$ respectively which was increased to $91.80 \mathrm{mg} / \mathrm{dl}, 101.00 \mathrm{mg} / \mathrm{dl}$ and $85.06 \mathrm{mg} / \mathrm{dl}$ and the overall value before the treatment was $70.85 \mathrm{mg} / \mathrm{dl}$ which was increased to $88.46 \mathrm{mg} / \mathrm{dl}$ in the exotic breed but in case of indigenous breed the level of glucose at the beginning $88.17 \mathrm{mg} / \mathrm{dl}$ which was increased to $88.40 \mathrm{mg} / \mathrm{dl}$ but it was not statistically significant $(\mathrm{P}>0.05)$, while comparing the glucose level of exotic and indigenous at the beginning of experiment there is significant variations but after the therapeutic regimens no variations were seen.
In case of serum total protein and globulin levels were also increased in all the categories of all animals with administration of hyper immune serum in comparison to their corresponding value with the beginning of the experiment. The overall total protein and globulin levels were $3.90 \mathrm{~g} / \mathrm{dl}$ and $1.17 \mathrm{~g} / \mathrm{dl}$ respectively with the beginning of the experiment which were increased to $5.29 \mathrm{~g} / \mathrm{dl}$ and $2.49 \mathrm{~g} / \mathrm{dl}$ respectively. No difference of total protein was seen between the exotic and indigenous breed of dog, but the globulin levels were significantly higher $2.90 \mathrm{~g} / \mathrm{dl}$ in indigenous breed in comparison to exotic $(2.49 \mathrm{~g} / \mathrm{dl})$. Whereas the serum albumin level does not vary with treatment, similarly as in case of globulin the albumin level of the indigenous dog was $3.8 \mathrm{~g} / \mathrm{dl}$ to which is significantly higher than the exotic dogs 2.83 $\mathrm{g} / \mathrm{dl}$. Serum creatinine level of the dog before treatment ranges from $1.30 \mathrm{mg} / \mathrm{dl}$ to 2.10 $\mathrm{mg} / \mathrm{dl}$ with an average of $1.45 \mathrm{mg} / \mathrm{dl}$. In exotic breeds before treatment and after treatment the levels were 1.02 to $1.56 \mathrm{mg} / \mathrm{dl}$ with an average of $1.21 \mathrm{mg} / \mathrm{dl}$ showing reducing level but not statistically not significant. The same trend was also observed in indigenous breed.

The blood urea nitrogen (BUN) of the exotic breed varied from $32.94 \mathrm{mg} / \mathrm{dl}$ to $36.32 \mathrm{mg} / \mathrm{dl}$ with an average of $35.83 \mathrm{mg} / \mathrm{dl}$ at the beginning of the experiment which was significantly decreased to a range of $20.40 \mathrm{mg} / \mathrm{dl}$ to $26.31 \mathrm{mg} / \mathrm{dl}$ having an average value of $25.00 \mathrm{mg} / \mathrm{dl}$. Similar trend also occurred in case of indigenous breed where the level of BUN was $36.67 \mathrm{mg} / \mathrm{dl}$ which was decreased to $20.60 \mathrm{mg} / \mathrm{dl}$ at the end of experiment or treatment. The liver enzymes like AST, ALT and ALP IU /L were estimated and the data showed that there was no variation due to treatment and also with the breeds except in case of ALT significantly higher value were seen $(90.4 \mathrm{IU} / \mathrm{L})$ in indigenous in comparisons to exotic dogs (76.50IU/L) after treatment. 
The electrolyte balance like Sodium, Potassium, Chloride and Bicarbonate were studied before and after treatment and compared with the breed also. The average value of Sodium in the exotic was $105.65 \mathrm{mmol} / \mathrm{L}$. In indigenous dog it was $107.3 \mathrm{mmol} / \mathrm{L}$ which was significantly increased to $129.67 \mathrm{mmol} / \mathrm{L}$ and $133.60 \mathrm{mmol} / \mathrm{L}$ respectively after treatment. Similarly, the serum Potassium level of the exotic breed was $2.60 \mathrm{mmol} / \mathrm{L}$ which was increased to $3.56 \mathrm{mmol} / \mathrm{L}$ and indigenous it was $2.36 \mathrm{mmol} / \mathrm{L}$ which increased to $3.08 \mathrm{mmol} / \mathrm{L}$ after treatment. The serum Chloride level also follows the same trend in both indigenous and exotic breed of dog. But the Bicarbonate level of the dog both in indigenous and exotic did not affect with the treatment. As the present dogs have the wide variation of age starting from 1 moth to 12 months. The data were segregated on the basis of age i.e. 1 to 3 months, 4 to 12 months\& more than 12 months of age both in exotic \& indigenous breed of dog.

The blood glucose level of the indigenous breed of 1 to 3 months of age was $93.33 \mathrm{mg} / \mathrm{dl}$ which was significantly higher $(\mathrm{P}<0.05)$ than the corresponding value i.e. $67.13 \mathrm{mg} / \mathrm{dl}$ in exotic dog. But in other age group no variation was observed among the breed and with the age. The serum total protein, albumin and globulin levels of the dog of different age group did not vary except in the age of more than 12 month of age group. The indigenous dog has a higher value than the exotic one. Similarly, the blood urea nitrogen (BUN) of the exotic and indigenous dog with the age did not vary significantly except in the age of more than 12 month of age. The exotic dog has higher BUN value than the indigenous. From the liver enzyme data, it was found that the AST value of 4 to 12 months of age in exotic dog was higher than the indigenous one in before treatment, but it was reversed in post treatment.

In case of ALT indigenous dog with 1 to 3 months of age has significantly higher value (91.00IU/L) than the exotic one (73.44IU/L) and also in the 4 to 12 months of age indigenous dog have higher value than exotic. Similarly, in ALP also both in 1 to 3 months and 4 to 12 months of age indigenous dog showed significantly higher $(\mathrm{P}<0.05)$ enzyme activity than the exotic dog in post treatment.

Serum electrolyte like sodium, potassium and chloride in both exotic and indigenous dog did not affect with the age, but it was showed a higher trend in after treatment. However, in chloride the indigenous dogs of more than 12 months of age have higher serum chloride value 100. $00 \mathrm{mmol} / \mathrm{L}$ than the exotic dog having a value of $71.60 \mathrm{mmol} / \mathrm{L}$. No effect of bicarbonate was observed neither with advancement of the age nor with the treatment.

The blood glucose level of the exotic dogs was increased with the treatment both in male and female dogs without any variations between the sex. In male the glucose level was $71.63 \mathrm{mg} / \mathrm{dl}$ with the beginning of the experiment which was increased to $85.71 \mathrm{mg} / \mathrm{dl}$ and in the female the level was $69.60 \mathrm{mg} / \mathrm{dl}$ and the corresponding value after treatment was $93.30 \mathrm{mg} / \mathrm{dl}$. But in case of indigenous significant variation of higher value of blood glucose level was seen which was $93.33 \mathrm{mg} / \mathrm{dl}$ with respect to $69.00 \mathrm{mg} / \mathrm{dl}$ in case of female. But after treatment no variation was marked between male and female. The serum total protein, albumin and globulin level of both exotic and indigenous dog significantly increased $(\mathrm{P}<0.05)$ with the values at the beginning of the experiment. But no variations were observed between the male and female of either of the breed. The $\mathrm{A} / \mathrm{G}$ ratio does not significantly vary with the treatment but comparatively lower ratio is observed in treated dogs. No, significant effect of serum creatinine value was seen between male and female and before and after treatment of the presented dogs. The BUN of dogs was significantly decreased after treatment in both exotic and indigenous dogs, but no difference was found between the male and female dogs. The liver enzymes like AST, ALT and ALP were estimated on the same day of collection of samples from infected dogs. No variation among the male and female dogs in both exotic and indigenous was observed. Similarly, serum electrolyte like sodium, 
potassium, chloride, and bicarbonate were compared between male and female. No difference was observed between the sex except serum chloride level of the indigenous male was significantly higher than $(74.00 \mathrm{mmol} / \mathrm{lt})$ than female $(62,67 \mathrm{mmol} / \mathrm{lt})$. But it was observed that the serum electrolyte value showed a significant higher value in post treatment than the pretreatment.

With respect to sero-biochemical parameters such as AST, ALT, ALP, BUN, Creatinine, Total Protein, Albumin, Globulin, A/G ratio and Glucose level a significant variation $(\mathrm{P}<0.05)$ were observed between the exotic and indigenous as well as before and after treatment group by both conventional and Hyper immune serum administration method of CPV infected dogs.

With respect to electrolyte imbalance of salt such as Sodium, Potassium, Chloride and Bicarbonate, a significant variation was observed between the exotic and indigenous as well as before and after treatment group by both traditional and Hyper immune serum administration method of CPV infected dogs.

\section{Acknowledgement}

The authors are very much grateful to the Director, TVCC and Dean, CVSc. And A.H., OUAT, Bhubaneswar for providing necessary facilities to carry out and complete the research work in time.

\section{References}

Appel MJG, Cooper BJ, Greisen $\mathrm{H}$ and Carmichael LE. 1978. Status Report: Canine Viral Enteritis. Journal of Animal Veterinary Medicine
Association.173:1516-1518.

Biswas S, Das PJ, Ghosh SK and Pradhan NR. 2006. Detection of canine parvovirus (CPV) DNA by polymerase chain reaction assay and its prevalence in dogs in and around Kolkata, West Bengal. Indian Journal of Animal Sciences, 76(4): 324-325.

Debram P. 2011. Parvoviral Enteritis (Parvo).Petplace.com.

Ettinger, Stephen J, Feldman and Edward C. 1995. Textbook of Veterinary Internal Medicine (4th Edn.). W.B. Saunders Company. ISBN 0-7216-6795-3.

Foster and Smith. 2011. Parvovirus. Serious Diarrhea in Puppies and Dogs Veterinary and Aquatic Services Department, Foster and Smith, Inc. 2253 Air Park Road, P.O. Box 100, Rhinelander, Wisconsin, 54501.

Houston DM, Ribble CS and Head LL. 1996. Risk factors associated with parvovirus enteritis in dogs: 283 cases (1982-1991). Journal of Animal Veterinary Medical Association, 208(4): 542-546.

Reddy KB, Shobhamani B, Sreedevi B, Prameela DR and Reddy BS. 2015. Canine parvo viral infection in dogs and their treatment. International Journal of Veterinary Science, 4(3): 142-144.

Yang DK, Kim B, Kim YH, Lee KW, Choi SS and Son SW. 2009. Genetic analysis of canine parvovirus vaccine strains in Korea. Korean Journal Veterinary Research, 49(3): 243-248.

Yilmaz Z, Pratelli A and Torun S.2005.Distribution of antigen types of canine parvovirus type-2 in dogs with hemorrhagic enteritis in Turkey. Turk Veterinerlikve Hayvancilik Dergisi, 29: 1073-1076.

\section{How to cite this article:}

Dash, S., M.R. Das, S.K. Senapati, G.R. Jena, S.K. Panda, S. Sathapathy and Nanda, S.M. 2019. Therapeutic Alternations of Sero-biochemical Parameters and Electrolyte Concentration in Canine Parvo Virus Infection. Int.J.Curr.Microbiol.App.Sci. 8(11): 1425-1431. doi: https://doi.org/10.20546/ijcmas.2019.811.167 